\title{
5-fluorouracil Toxicity Mechanism Determination in Human Keratinocytes: in vitro Study on HaCaT Cell Line
}

\section{Jan Hartinger ${ }^{1}$, Pavel Veselý ${ }^{2}$, Martin Šíma ${ }^{1}$, Irena Netíková ${ }^{1}$,} Eva Matoušková ${ }^{3}$, Luboš Petruželka ${ }^{4}$

${ }^{1}$ Department of Clinical Pharmacology and Pharmacy, Institute of Pharmacology, First Faculty of Medicine, Charles University and General University Hospital in Prague, Prague, Czech Republic;

${ }^{2}$ Central European Institute of Technology, Brno University of Technology, Brno, Czech Republic;

${ }^{3}$ Department of Burns Medicine, Third Faculty of Medicine, Charles University and University Hospital Královské Vinohrady, Prague, Czech Republic; ${ }^{4}$ Department of Oncology, First Faculty of Medicine, Charles University and General University Hospital in Prague, Prague, Czech Republic

Received June 29, 2017; Accepted December 5, 2017.

Key words: 5-fluorouracil - Uridine - Thymidine - Calciumfolinate Keratinocytes

Abstract: 5-fluorouracil (5-FU) and capecitabine therapy is often accompanied by palmar-plantar erythrodysesthesia (PPE) which is manifestation of 5-FU toxicity in keratinocytes. The main mechanisms of 5-FU action are thymidylate synthase (TS) inhibition which can be abrogated by thymidine and strengthened by calciumfolinate (CF) and incorporation of fluorouridinetriphosphate into RNA which can be abrogated by uridine. For proper PPE treatment 5-FU mechanism of action in keratinocytes needs to be elucidated. We used the 5-FU toxicity modulators uridine, thymidine and CF to discover the mechanism of 5-FU action in human keratinocyte cell line $\mathrm{HaCaT}$.To measure the cellular viability, we used MTT test and RTCA test. CF did not augment 5-FU toxicity and 5-FU toxicity was weakened by uridine. Therefore, the primary mechanism of 5-FU toxicity in keratinocytes is 5-FU incorporation into RNA. The uridine protective effect

This study was supported by the Charles University grant UNCE 204022.

Mailing Address: Mgr. Jan Hartinger, Department of Clinical Pharmacology and Pharmacy, Institute of Pharmacology, First Faculty of Medicine, Charles University and General University Hospital in Prague, Na Bojišti 1, 12800 Prague 2, Czech Republic; Phone: +420 224964 135; e-mail: hartinger.jan@vfn.cz 
cannot fully develop in the presence of CF.Thymidine addition to 5-FU and uridine treated cells not only prevents the toxicity-augmenting CF effect but it also prolongs the 5-FU treated cells survival in comparison to uridine only. Therefore, it can be assumed that in the presence of uridine the 5-FU toxicity mechanism is switched from RNA incorporation to TS inhibition. Although particular 5-FU toxicity mechanisms were previously described in various cell types, this is the first time when various combinations of pyrimidine nucleosides and CF were used for 5-FU toxicity mechanism elucidation in human keratinocytes. We suggest that for PPE treatment ointment containing uridine and thymidine should be further clinically tested.

\section{Introduction}

5-fluorouracil (5-FU) and its peroral prodrug capecitabine are the cornerstone cytostatics in the treatment of various tumours especially colorectal carcinoma (Longley et al., 2003; Engstrom et al., 2009; Schmoll et al., 2012). Palmar-plantar erythrodysesthesia (PPE) is 5-FU adverse event that occurs when 5-FU is applied as continuous infusion (Lokich et al., 1989; Wolpin and Mayer, 2008) and accompanies also the long-term capecitabine peroral therapy in as much as $60 \%$ of patients (Leonard et al., 2011; Hofheinz et al., 2012). This makes PPE one of the most frequent capecitabine adverse events (Biganzoli et al., 2002; Yun et al., 2010; Leonard et al., 2011). PPE is caused by keratinocyte reaction to the cytotoxic compound presented in the skin (Janusch et al., 2006). So far no satisfactory PPE treatment is available. One of the treatment approaches is local 5 -FU antidote application which does not influence systemic 5-FU efficacy (Barth, 2004; Netíková et al., 2009). Nowadays no ideal locally applied antidote becomes widely recognized as effective. Pharmacy compounded $10 \%$ uridine ointment is used as empirical clinical praxis in several oncology centers in Europe (Barth, 2004; Netíková et al., 2009). No randomized controlled trials support this treatment and placebo effect or ointment base effect cannot be ruled out. Different 5-FU toxicity mechanism occurs in different cell types (Umeda and Heidelberger, 1968; Martin et al., 1980; van Groeningen et al., 1992). The particular mechanism of 5-FU toxicity in keratinocytes needs to be elucidated for locally applicable PPE antidote development. Therefore, we aimed to find out the particular 5-FU toxicity mechanism in these cells to help the best local antidote ointment development.

Two main biological mechanisms of 5-FU action are thymidylate synthase (TS) inhibition by fluorodeoxyuridinmonophosphate (FdUMP) and fluorouridintriphosphate (FUTP) incorporation into RNA. FdUMP-TS complex is further stabilized by reduced folic acid which normally serves as methyl donor for uridinemonophosphate (UMP) to thymidylate (TMP) conversion. Consequently, high concentration of dUTP occurs in the cell which leads to dUTP incorporation into DNA and subsequent DNA damage (Martin et al., 1980; Longley et al., 2003). TS inhibition can be abrogated by adding of thymidine, which is metabolized by thymidinkinase to 
thymidylate without contribution of TS (Umeda and Heidelberger, 1968). Therefore, in the presence of thymidine the 5-FU effect on DNA is weakened which leads to more pronounced effect on RNA mediated by fluorouridintriphosphate (FUTP) incorporation into RNA and subsequent RNA function disruption (Martin et al., 1980; Longley et al., 2003) which is preventable by uridine (Sawyer et al., 1984; Codacci-Pisanelli et al., 2008).

The 5-FU toxicity modulators can be used for studying the particular 5-FU toxicity mechanism in particular cell line (Umeda and Heidelberger, 1968; Codacci-Pisanelli et al., 2008). If 5-FU toxicity is strengthened by calciumfolinate (CF) addition, the TS inhibition plays significant role whereas if the 5-FU toxicity is not augmented by CF, RNA toxicity is main mechanism of $5-F U$ action. If the toxicity decreases after uridine addition, the 5-FU incorporation into RNA plays important role (Codacci-Pisanelli et al., 2008). If the toxicity is lowered after thymidine addition which abrogates TS inhibition, DNA toxicity is the major mechanism of 5-FU action (Umeda and Heidelberger, 1968) whereas opposite effect of thymidine addition means that augmentation of the 5-FU incorporation to RNA results in more toxic effect than TS inhibition (Martin et al., 1980). Here we studied the 5-FU mechanism of action in human spontaneously immortalized $\mathrm{HaCaT}$ cell line by adding various combinations of uridine, thymidine and $\mathrm{CF}$ to the cell culture medium.

\section{Material and Methods}

Cultivation of HaCaT keratinocytes

$\mathrm{HaCaT}$ cells were kindly provided by professor Dr. J. Bereiter-Hahn, Kinematic Cell Research Group, Institute for Cell Biology and Neurosciences, Goethe University Frankfurt am Main, Germany. HaCaT cells are a spontaneously immortalized human epithelial cell line that maintains the full epidermal differentiation capacity (Boukamp et al., 1988). The cells were cultured in the H-MEM medium supplemented with non-essential amino acids, $0.12 \mathrm{~g} / \mathrm{l}$ sodium pyruvate, $1 \mathrm{~g} / \mathrm{l}$ $\mathrm{NaHCO}_{3}, 10 \%$ bovine serum, $2 \%$ fetal bovine serum and antibiotics $(200 \mathrm{U} / \mathrm{ml}$ penicillin and $100 \mu \mathrm{g} / \mathrm{ml}$ streptomycin). The cells were maintained in the humidified atmosphere at $37^{\circ} \mathrm{C}$ and $3.5 \% \mathrm{CO}_{2}$.

\section{MTT test}

We tested the effect of uridine, thymidine and CF on cells treated with various 5-FU concentrations. We used the MTT test described elsewhere (Mosmann, 1983). The cells were plated into 96 -well plate (14 000 cells per well in $100 \mu \mathrm{l}$ of the medium without phenol red). The outer wells were not seeded with cells but filled with sterile water for injection. When cellular layers were almost confluent, $100 \mu \mathrm{l}$ of the tested agents dissolved in the medium were added to the wells. For each of the protective substances settings (5-FU various concentrations, nucleosides and CF combinations) 9 wells were used. The metabolic activity 
was measured after 2, 4 and 7 days of cultivation. $10 \mu \mathrm{l}$ of MTT (5 mg/ml in PBS) was added into three of the wells with each particular compound combination. After six hours of incubation the formazan production was stopped by $100 \mu \mathrm{l}$ of the $10 \%$ SDS solution in distilled water. After overnight incubation the plates were analyzed by the ELISA reader $(570 \mathrm{~nm}$ test wavelength and the $630 \mathrm{~nm}$ background wavelength). The mean values of absorbance from the wells with the same concentration of the tested agents ( 3 for each setting) were considered as indicators of the cellular metabolic activity. The higher absorbance was measured the more viability of the cells.

RTCA (xCELLigence)

We tested the effect of uridine, thymidine and CF on cells treated with $7.5 \mu \mathrm{g} / \mathrm{ml}$ 5-FU concentration. We used the Real Time Cell Analyser produced by Roche Applied Sciences (xCELLigence). Fourteen thousand cells in the $100 \mu \mathrm{l}$ medium were plated into the wells of a 96-well plate. Each well is provided with golden electrodes on the bottom surface. The measurable impedance between these two electrodes increases when the cells are growing and dividing. The cell surface changes and the adhesion and morphology changes play a role in this measurement, too. As a result, we obtain the "cell index" derived from the above-mentioned cellular properties. The cell index can be generally considered as the cellular viability indicator with some limitations (Atienzar et al., 2011). The outer wells were not used as the cells in these wells are frequently affected by evaporation. The tested substances diluted in $100 \mu \mathrm{l}$ of the medium were added when the cell index plot curves were growing exponentially. The cell index value was recorded every 3.5 hours for 6 days. In the plot the mean value of cell index derived from 3 wells for each tested compounds combination is presented. Time 0 represents the time of adding the tested compounds.

\section{The tested substances}

Uridine and thymidine were obtained as $>99 \%$ powder in cell-culture suitable quality from Sigma-Aldrich (SIGMA-ALDRICH s. r. o., Prague, Czech Republic). 5-FU was obtained as a $50 \mathrm{mg} / \mathrm{ml}$ solution in water for injection and calciumfolinate was obtained as a $10 \mathrm{mg} / \mathrm{ml}$ solution in water for injection from local hospital pharmacy (both from EBEWE Pharma Ges. m. b. H. Nfg. KG, Unterach, Austria). All tested substances were further diluted in the cell culture medium without addition of any solvent. The calciumfolinate was tested in $20 \mu \mathrm{g} / \mathrm{ml}$ concentration. Uridine was tested in $50 \mu \mathrm{g} / \mathrm{ml}$ and thymidine was tested in $25 \mu \mathrm{g} / \mathrm{ml}$ concentration. 5-FU was tested in 4.8, 7.6, 12.2, 9.5 and $31.3 \mu \mathrm{g} / \mathrm{ml}$ concentrations.

\section{Statistics}

To compare the MTT test cellular viability results and RTCA cell index differences we used student's $t$-test. 


\section{Results}

The metabolic activity and surface adherence of keratinocytes did not differ significantly when calciumfolinate was added to the 5-FU treated cells (Figures $1 \mathrm{~A}$ and $\mathrm{B}$ and $4 \mathrm{~A}$ ). The 5 -FU toxicity was directly proportional to the 5-FU concentration on day 4 (Figure 1B). On day 7 all cells without nucleosides were already dead because of 5-FU toxicity in MTT test (results not shown) and in RTCA test (Figure 4A).

Uridine addition lowered 5-FU toxicity in $\mathrm{HaCaT}$ cells (Figures 2 and 4B). The toxicity of 5-FU was pronounced to the similar extent on the day 4 irrespectively on the 5-FU concentration when uridine without CF was added (Figure 2B). When $\mathrm{CF}$ was added to the 5-FU-uridine combination, the protective effect of uridine was weakened and the toxicity of 5-FU was significantly augmented (Figures 2

A. Day 2:5-FU only and 5-FU + calciumfolinate

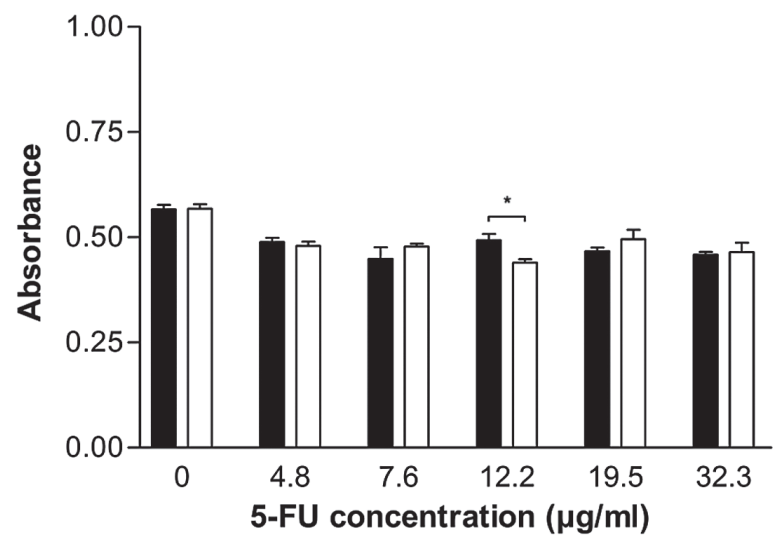

B. Day 4:5-FU only and 5-FU + calciumfolinate

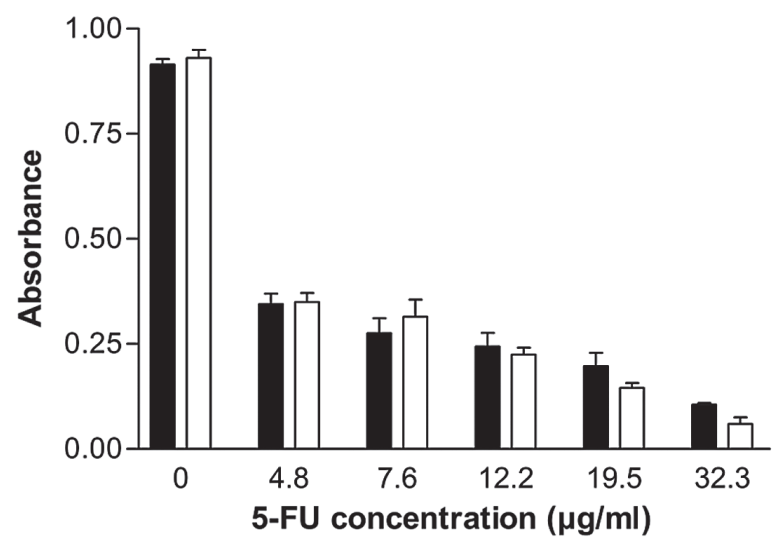

Figure 1 - Metabolic activity of $\mathrm{HaCaT}$ cells measured by MTT test. The higher the absorbance is the higher the metabolic activity. Comparison of cells treated with 5-FU only (black columns) and with 5-FU together with $20 \mu \mathrm{g} / \mathrm{ml}$ calciumfolinate (white columns).

Calciumfolinate addition to 5-FU treated cells did not augment the 5-FU toxicity in days $2(A)$ and $4(B)(* p<0.05)$. 
A. Day 2: Uridine protective effect against 5-FU toxicity is lowered by calciumfolinate addition

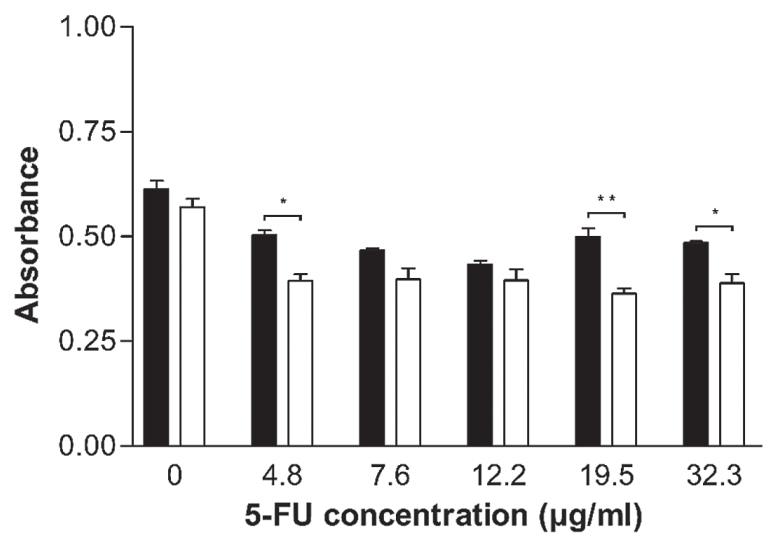

B. Day 4: Uridine protective effect against 5-FU toxicity is lowered by calciumfolinate addition

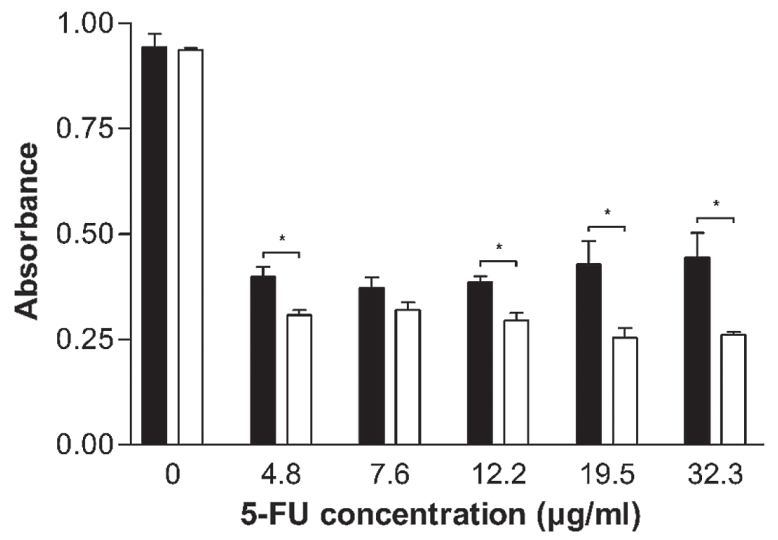

Figure 2 - Metabolic activity of $\mathrm{HaCaT}$ cells measured by MTT test. The higher the absorbance is the higher the metabolic activity. Comparison of cells treated with $5-\mathrm{FU}+$ uridine $(50 \mu \mathrm{g} / \mathrm{ml})$ without CF (black columns) and cells treated with $5-\mathrm{FU}+$ uridine $(50 \mu \mathrm{g} / \mathrm{ml})$ with $20 \mu \mathrm{g} / \mathrm{ml}$ calciumfolinate (white columns). Calciumfolinate addition to $5-\mathrm{FU}+$ uridine treated cells augmented the 5-FU toxicity in days $2(A)$ and $4(B)$ $(* p<0.05, * * p<0.01)$.

and $4 \mathrm{~B})$. On day 4 the $\mathrm{CF}$ effect was significantly more pronounced in higher 5-FU concentrations (Figure 2B). On day 7 all cells were already dead in MTT (results not shown) and RTCA test (Figure 4B).

When uridine, together with thymidine were added to the cells treated with 5-FU CF did not augment the 5-FU toxicity and most of the cells survived till day 7 in MTT (Figure 3C) and RTCA (Figure 4C) test. On day 7 the 5-FU toxicity was more pronounced in higher 5-FU concentrations in MTT test (Figure 3C).

\section{Discussion}

Although particular 5-FU toxicity mechanism were previously described for various cell types (Codacci-Pisanelli et al., 2008), this is the first time when 
A. Day 2: Uridine and thymidine protective effect is not lowered by calciumfolinate addition

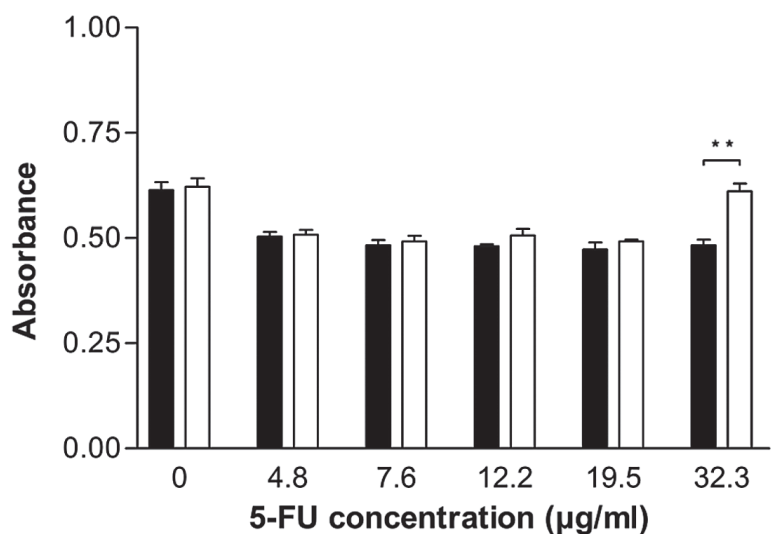

B. Day 4: Uridine and thymidine protective effect is not lowered by calciumfolinate addition

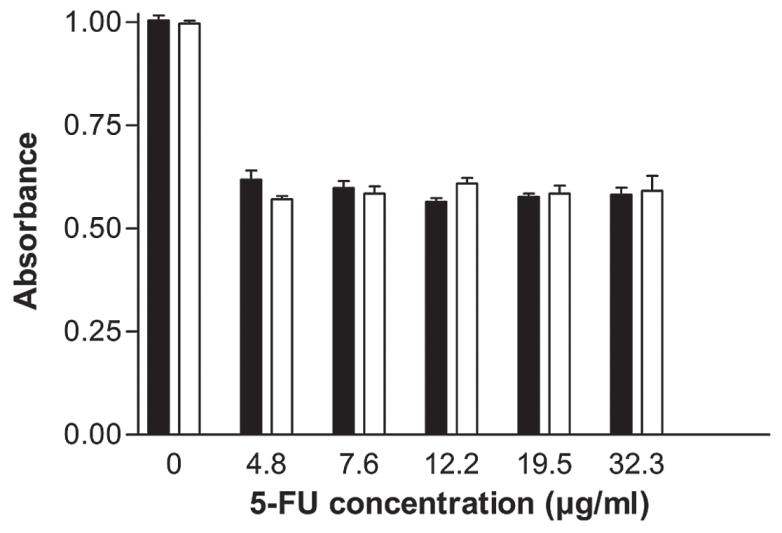

C. Day 7: Uridine and thymidine protective effect is not lowered by calciumfolinate addition

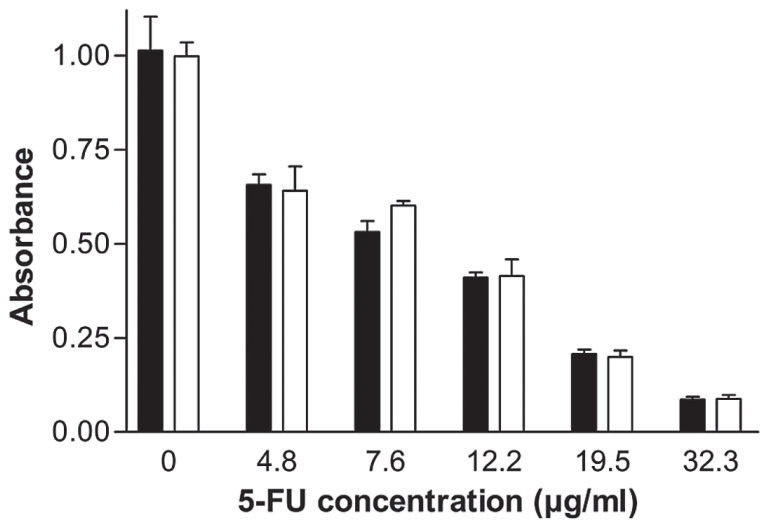

Figure 3 - Metabolic activity of $\mathrm{HaCaT}$ cells measured by MTT test. The higher the absorbance is the higher the metabolic activity. Comparison of cells treated with $5-\mathrm{FU}+$ uridine $(50 \mu \mathrm{g} / \mathrm{ml})$ + thymidine $(25 \mu \mathrm{g} / \mathrm{ml})$ without $\mathrm{CF}$ (black columns) and cells treated with 5-FU + uridine $(50 \mu \mathrm{g} / \mathrm{ml})$ + thymidine $(25 \mu \mathrm{g} / \mathrm{ml})$ with $20 \mu \mathrm{g} / \mathrm{ml}$ calciumfolinate (white columns). Calciumfolinate addition to the 5-FU treated cells did not augment the 5-FU toxicity in the presence of uridine and thymidine combination in days 2 (A), 4 (B) and 7 (C) $(* * p<0.01)$. 
A. 5-FU only

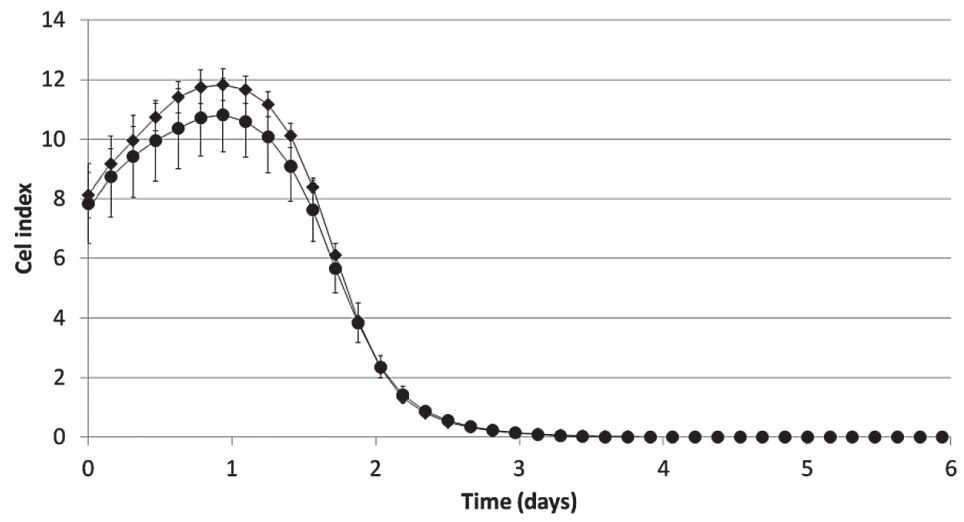

B. 5-FU + uridine

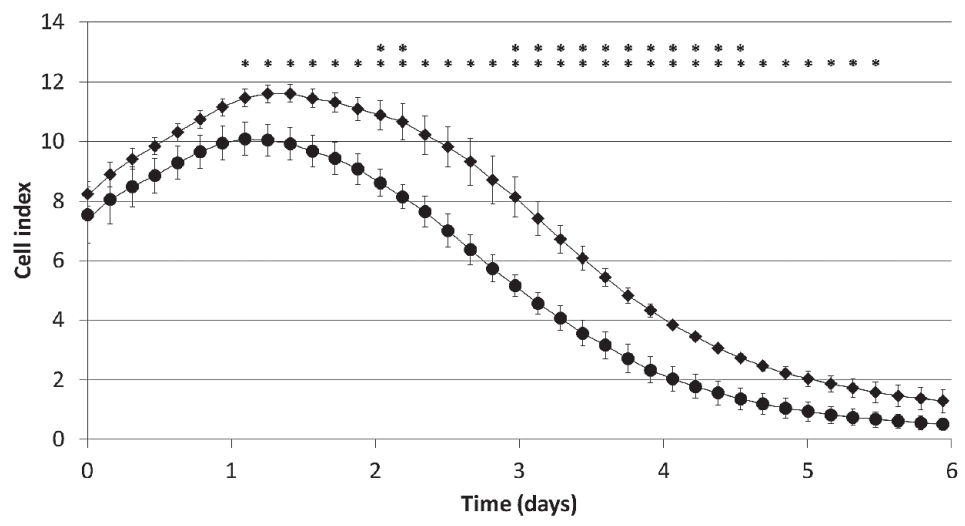

C. 5-FU + uridine and thymidine

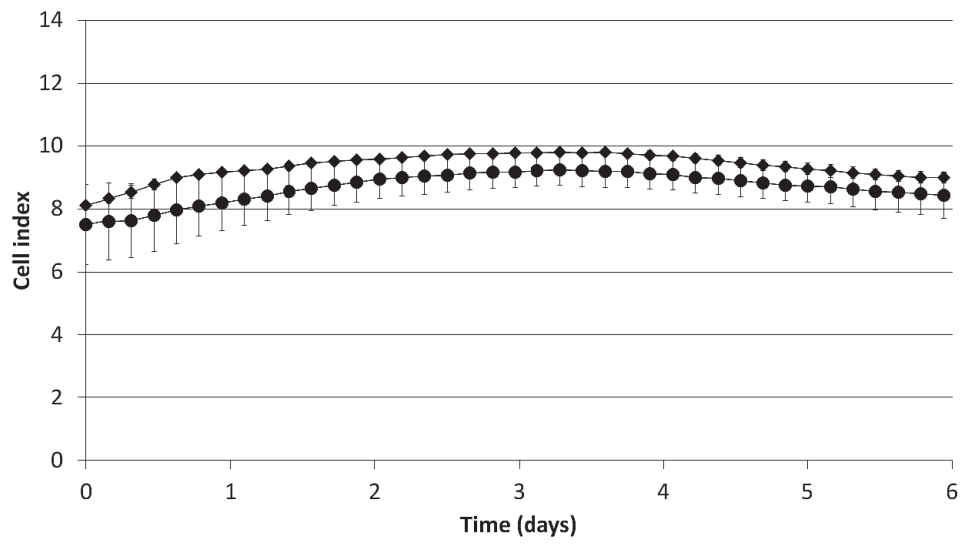

Figure 4 - Effect of calciumfolinate addition to the 5-FU $(7.5 \mu \mathrm{g} / \mathrm{ml})$ treated cells $(\mathrm{A}), 5-\mathrm{FU}(7.5 \mu \mathrm{g} / \mathrm{ml})+$ uridine $(50 \mu \mathrm{g} / \mathrm{ml})$ treated cells (B) and 5-FU $(7.5 \mu \mathrm{g} / \mathrm{ml})+$ uridine $(50 \mu \mathrm{g} / \mathrm{ml})$ and thymidine $(25 \mu \mathrm{g} / \mathrm{ml})$ treated cells (C). Diamonds - cells without calciumfolinate, circles - cells with $20 \mu \mathrm{g} / \mathrm{ml}$ calciumfolinate $\left({ }^{*} p<0.05,{ }^{* *} p<0.01\right)$. 
various combinations of pyrimidine nucleosides and CF were used for 5-FU toxicity mechanism elucidation in human keratinocytes. We confirmed that CF did not augment the 5-FU toxicity in keratinocytes (Figures $1 \mathrm{~A}$ and B and 4A). Similarly as in other non-tumorous tissues (Sawyer et al., 1984; Bagrij et al., 1993; Codacci-Pisanelli et al., 1997, 2008; Pritchard et al., 1997) the primary mechanism of 5-FU action in keratinocytes is therefore mediated by its incorporation into RNA. We have shown that this primary mechanism of 5-FU toxicity in $\mathrm{HaCaT}$ keratinocytes is preventable by uridine (Figure 2A and B). Our results also show that uridine addition "switches" the toxicity mechanism from 5-FU RNA incorporation to TS inhibition because CF strengthened the 5-FU toxicity when added to the 5-FU + uridine treated cells (Figures $2 \mathrm{~A}$ and $\mathrm{B}$ and $4 \mathrm{~B}$ ). When thymidine is added to the 5-FU + uridine treated cells both of the two main 5-FU toxicity mechanisms are prevented and the cells survive significantly longer than those treated by uridine only (Figures $3 \mathrm{C}$ and $4 \mathrm{C}$ ). CF did not augment the 5-FU toxicity when thymidine was added to the cell medium because of the TS inhibition was abrogated (Figures $3 \mathrm{~A}-\mathrm{C}$ and $4 \mathrm{C}$ ). In the presence of uridine and thymidine combination the toxicity of $5-\mathrm{FU}$ was more pronounced in higher concentrations of 5-FU on day 7 (Figure 3C). Because of the aforementioned absence of CF effect this toxicity cannot be adjudged to TS inhibition. When both main 5-FU toxicity mechanisms are abrogated by uridine and thymidine, other minor toxicity mechanisms may become important (Bagrij et al., 1993; Wurzer et al., 1994; An et al., 2007; Yen-Revollo et al., 2008).

5-FU DNA incorporation (An et al., 2007) may became important in higher 5-FU concentrations. Because 5-FU DNA incorporation would be at least partially preventable in the surplus of thymidine, lower 5-FU concentration toxicity would be prevented but higher 5-FU concentrations toxicity would be preserved. 5-FU degradation product toxicity (Yen-Revollo et al., 2008) or unmetabolized 5-FU toxicity (Bagrij et al., 1993;Wurzer et al., 1994) may also play role in higher 5 -FU concentrations.

\section{Conclusion}

Our results show that not only the cell type and state (e. g. frequency of mitoses and amount of DNA synthesis) but also its environment e. g. amount of nucleosides in the cell surrounding predisposes the cells for particular 5-FU toxicity mechanism development. In human keratinocytes RNA toxicity preventable by uridine is the primary mechanism of 5-FU action. In the presence of uridine TS inhibition becomes more important. This can be further abrogated by thymidine. In the development of local antidote ointment in PPE treatment it is favourable to antagonize most of the probable 5-FU toxicity mechanisms. Therefore, our findings should be considered when developing the most potent local antidote ointment for 5-FU induced skin adverse events. 


\section{References}

An, Q., Robins, P., Lindahl, T., Barnes, D. E. (2007) 5-fluorouracil incorporated into DNA is excised by the Smug1 DNA glycosylase to reduce drug cytotoxicity. Cancer Res. 67, 940-945.

Atienzar, F. A., Tilmant, K., Gerets, H. H., Toussaint, G., Speeckaert, S., Hanon, E., Depelchin, O., Dhalluin, S. (2011) The use of real-time cell analyzer technology in drug discovery: Defining optimal cell culture conditions and assay reproducibility with different adherent cellular models. J. Biomol. Screen. 16, 575-587.

Bagrij, T., Kralovanszky, J., Gyergyay, F., Kiss, E., Peters, G. J. (1993) Influence of uridine treatment in mice on the protection of gastrointestinal toxicity caused by 5-fluorouracil. Anticancer Res. 13, 789-793.

Barth, J. (2004) Letter to the editor - 5-FU induced palmar-plantar erythrodyesthesia - a hospital pharmacy developed "antidot".J. Oncol. Pharm. Pract. 10, 57.

Biganzoli, L., Martin, M., Twelves, C. (2002) Moving forward with capecitabine: a glimpse of the future. Oncologist 7, 29-35 (Suppl. 6).

Boukamp, P., Petrussevska, R. T., Breitkreutz, D., Hornung, J., Markham, A., Fusenig, N. E. (1988) Normal keratinization in a spontaneously immortalized aneuploid human keratinocyte cell line.J. Cell Biol. 106, 761-771.

Codacci-Pisanelli, G., Kralovanszky, J., van der Wilt, C. L., Noordhuis, P., Colofiore, J. R., Martin, D. S., Franchi, F., Peters, G. J. (1997) Modulation of 5-fluorouracil in mice using uridine diphosphoglucose. Clin. Cancer Res. 3, 309-315.

Codacci-Pisanelli, G., Noordhuis, P., van der Wilt, C. L., Peters, G. J. (2008) Selective protection by uridine of growth inhibition by 5 -fluorouracil (5FU) mediated by $5 \mathrm{FU}$ incorporation into RNA, but not the thymidylate synthase mediated growth inhibition by $5 F U$-leucovorin. Nucleosides Nucleotides Nucleic Acids 27, 733-739.

Engstrom, P. F., Arnoletti, J. P., Benson, A. B. $3^{\text {rd }}$, Chen, Y. J., Choti, M. A., Cooper, H. S., Covey, A., Dilawari, R. A., Early, D. S., Enzinger, P. C., Fakih, M. G., Fleshman, J. Jr., Fuchs, C., Grem, J. L., Kiel, K., Knol, J. A., Leong, L. A., Lin, E., Mulcahy, M. F., Rao, S., Ryan, D. P., Saltz, L., Shibata, D., Skibber, J. M., Sofocleous, C., Thomas, J., Venook, A. P., Willett, C. (2009) NCCN Clinical Practice Guidelines in Oncology: colon cancer. J. Natl. Compr. Canc. Netw. 7, 778-831.

Hofheinz, R. D., Heinemann, V., von Weikersthal, L. F., Laubender, R. P., Gencer, D., Burkholder, I., Hochhaus, A., Stintzing, S. (2012) Capecitabine-associated hand-foot-skin reaction is an independent clinical predictor of improved survival in patients with colorectal cancer. Br. J. Cancer 107, 1678-1683.

Janusch, M., Fischer, M., Marsch, W. C., Holzhausen, H. J., Kegel, T., Helmbold, P. (2006) The hand-foot syndrome - A frequent secondary manifestation in antineoplastic chemotherapy. Eur. J. Dermatol. 16, 494-499.

Leonard, R., Hennessy, B. T., Blum, J. L., O’Shaughnessy, J. (2011) Dose-adjusting capecitabine minimizes adverse effects while maintaining efficacy: a retrospective review of capecitabine for metastatic breast cancer. Clin. Breast Cancer 11, 349-356.

Lokich, J. J., Ahlgren, J. D., Gullo, J. J., Philips, J. A., Fryer, J. G. (1989) A prospective randomized comparison of continuous infusion fluorouracil with a conventional bolus schedule in metastatic colorectal carcinoma: a Mid-Atlantic Oncology Program Study. J. Clin. Oncol. 7, 425-432.

Longley, D. B., Harkin, D. P., Johnston, P. G. (2003) 5-fluorouracil: Mechanisms of action and clinical strategies. Nat. Rev. Cancer 3, 330-338.

Martin, D. S., Stolfi, R. L., Sawyer, R. C., Nayak, R., Spiegelman, S., Young, C.W., Woodcock, T. (1980) An overview of thymidine. Cancer 45, 1117-1128.

Mosmann, T. (1983) Rapid colorimetric assay for cellular growth and survival: Application to proliferation and cytotoxicity assays. J. Immunol. Methods 65, 55-63. 
Netíková, I., Sedláčková, E., Konopásek, B., Petruželka, L. (2009) Therapy of palmar-plantar erythrodysesthesia after continual fluoropyrimidin administration with $10 \%$ uridin ointment (ASCO Meeting Abstract). J. Clin. Oncol. 27.

Pritchard, D. M., Watson, A. J., Potten, C. S., Jackman, A. L., Hickman, J. A. (1997) Inhibition by uridine but not thymidine of $\mathrm{p} 53$-dependent intestinal apoptosis initiated by 5 -fluorouracil: evidence for the involvement of RNA perturbation. Proc. Natl. Acad. Sci. U. S. A. 94, 1795-1799.

Sawyer, R. C., Stolfi, R. L., Spiegelman, S., Martin, D. S. (1984) Effect of uridine on the metabolism of 5-fluorouracil in the CD8F 1 murine mammary carcinoma system. Pharm. Res. 1, 69-75.

Schmoll, H. J., Van Cutsem, E., Stein, A., Valentini, V., Glimelius, B., Haustermans, K., Nordlinger, B., van de Velde, C. J., Balmana, J., Regula, J., Nagtegaal, I. D., Beets-Tan, R. G., Arnold, D., Ciardiello, F., Hoff, P., Kerr, D., Kohne, C. H., Labianca, R., Price, T., Scheithauer, W., Sobrero, A., Tabernero, J., Aderka, D., Barroso, S., Bodoky, G., Douillard, J.Y., El Ghazaly, H., Gallardo, J., Garin, A., Glynne-Jones, R., Jordan, K., Meshcheryakov, A., Papamichail, D., Pfeiffer, P., Souglakos, I., Turhal, S., Cervantes, A. (2012) ESMO Consensus Guidelines for management of patients with colon and rectal cancer. a personalized approach to clinical decision making. Ann. Oncol. 23, 2479-2516.

Umeda, M., Heidelberger, C. (1968) Comparative studies of fluorinated pyrimidines with various cell lines. Cancer Res. 28, 2529-2538.

van Groeningen, C. J., Peters, G. J., Pinedo, H. M. (1992) Modulation of fluorouracil toxicity with uridine. Semin. Oncol. 19, 148-154.

Wolpin, B. M., Mayer, R. J. (2008) Systemic treatment of colorectal cancer. Gastroenterology 134, 1296-1310.

Wurzer, J. C., Tallarida, R. J., Sirover, M. A. (1994) New mechanism of action of the cancer chemotherapeutic agent 5-fluorouracil in human cells. J. Pharmacol. Exp. Ther. 269, 39-43.

Yen-Revollo, J. L., Goldberg, R. M., McLeod, H. L. (2008) Can inhibiting dihydropyrimidine dehydrogenase limit hand-foot syndrome caused by fluoropyrimidines? Clin. Cancer Res. 14, 8-13.

Yun, J. A., Kim, H. C., Son, H. S., Kim, H. R., Yun, H. R., Cho, Y. B., Yun, S. H., Lee, W. Y., Chun, H. K. (2010) Oncologic outcome after cessation or dose reduction of capecitabine in patients with colon cancer. J. Korean Soc. Coloproctol. 26, 287-292. 